In conclusion, I have tried to present an appraisal of the present state of knowledge in this field. Whether this is interpreted as indicating that nutrition is an imprecise science or a fascinating but complex multidiscipline depends upon one's point of view. Certainly in the evaluation of diets there are still many problems to be solved, but to quote Professor Platt, who initiated much of the work, "the ability to ask the right questions is three parts of the way to solving them'.

\title{
REFERENCES
}

Culwick, G. M. (195I). Diet in the Gezira Irrigated Area, Sudan. Publ. no. 304. Khartoum: Sudan Survey Department.

Dema, I. S., Miller, D. S. \& Platt, B. S. (1959). Proc. Nutr. Soc. 18, xi.

FAO (I 966 ). St. Fd Agric.

Friend, C. J., Heard, C. R. C., Platt, B. S., Stewart, R. J. C. \& Turner, M. R. (r96r). Br. F. Nutr. $15,23 \mathrm{I}$.

Jelliffe, D. B. (1966). Monograph Ser. W.H.O. no. 53.

McCance, R. A. \& Widdowson, E. M. (editors). (1968). Calorie Deficiencies and Protein Deficiencies. London: J. \& A. Churchill Ltd.

Miller, D. S. \& Payne, P. R. (1969). Proc. Nutr. Soc. 28, 225.

Orraca-Tetteh, R. \& Platt, B. S. (1964). Proc. Nutr. Soc. 23, iii.

Platt, B. S. (1945). Spec. Rep. Ser. med. Res. Coun. no.253.

Platt, B. S. (1962). Spec, Rep. Ser. med. Res. Coun. no. 302.

Platt, B. S., Eddy, T. P. \& Pellett, P. L. (I963). Food in Hospitals. London: Oxford University Press.

Platt, B. S. \& Miller, D. S. (1958). Proc. Nutr. Soc. 17, ro6.

Platt, B. S. \& Miller, D. S. (1959). Proc. Nutr. Soc. 18, vii.

Platt, B. S., Miller, D. S. \& Payne, P. R. (Ig6r). In Recent Advances in Human Nutrition p. 35 I [J. F. Brock, editor]. London: J. \& A. Churchill Ltd.

WHO (1963). Tech. Rep. Ser. Wld Hlth Org. no. 258.

Yudkin, J. (1968). Science Y. 4, 48 .

\section{Interrelationship of the human intestinal flora and protein utilization}

\author{
By H. A. P. C. OOMEN, Department of Tropical Hygiene, \\ Royal Tropical Institute, Amsterdam
}

Body size, physical fitness and functional performance of persons usually subsisting on rations well below formulated requirements often cannot be understood. In the poor cassava-eating regions of Java, periodic hunger-oedema is of common occurrence; in the sweet-potato-eating highlands of New Guinea, where the diet is essentially similar in macro-nutrients, it is a rarity, and, in addition, physique is often manifestly superior. Despite the fact that in this environment the small child is weaned from breast milk on to a nearly exclusive diet of cooked sweet-potato, protein malnutrition is not regularly observed even when it could reasonably be expected. Bailey ( 1963 ), one of the investigators who were struck by the paradoxical physical performance in sweet-potato eaters, remarked 'that we are in fact dealing with a highly specialized adaptation to a particular way of life'. This would mean a nutritional adaptation, a much more intrinsic mechanism than the enlargement of the thyroid in iodine deficiency, the increase in haemoglobin at low oxygen pressure or the regulation of peripheral circulation in heat or cold tolerance. 
Observations on sweet-potato eaters

In 1967 we investigated nitrogen metabolism in representative groups and under strictly native conditions in one of the mountain districts of Australian New Guinea (Oomen \& Corden, I970). We selected Mount Hagen district because of the robust appearance of these ethnic groups. The number of tourists impressed by their 'splendid physique' is growing daily. A high percentage of the highland people have to rely on sweet-potato as their staff of life (Oomen, Spoon, Heesterman, Ruinard, Luyken \& Slump, I96I). Of the calories of the common fare, $80-90 \%$ is usually provided by this one tuber, which is present in a large number of strains. The percentage of calories derived from protein of the common varieties is only about 4 . The total calorie intake is generally satisfactory.

The tubers are always consumed boiled or baked. High-protein foods, either vegetable or animal, play a very minor part in this environment. We suspected that the superior physique and performance of the Mount Hagen people were connected with either protein-rich sweet-potato varieties or with ample consumption of leaves. None of these suspicions could be confirmed. The common varieties contained only $\mathbf{I}-\mathbf{I} \cdot \mathbf{I} \%$ crude protein, whereas the consumption of leaf-vegetables and legumes was negligible. As a result, food $\mathrm{N}$ intake in local experimental subjects varied between 2.5 and $3.8 \mathrm{~g} \mathrm{~N} / 24 \mathrm{~h}$. The $\mathrm{N}$ excreted by urine varied between $2 \cdot 6$ and $2.9 \mathrm{~g} \mathrm{~N} / 24 \mathrm{~h}$; the faecal $\mathrm{N}$ between $2 . \mathrm{I}$ and $2.5 \mathrm{~g} \mathrm{~N} / 24 \mathrm{~h}$; the total $\mathrm{N}$ output varied between 4.7 and $5.4 \mathrm{~g} / 24 \mathrm{~h}$ (Fig. IB). All the twenty-three sweet-potato eaters thus proved to be in a negative $\mathrm{N}$ balance with a deficit of about $2 \mathrm{~g}$. A control group consisting of eleven Papuans of similar size but used to a rice-wheat diet providing about $\mathrm{I} 4 \mathrm{~g} \mathrm{~N} / 24 \mathrm{~h}$, proved as expected to be in $\mathrm{N}$ equilibrium (Fig. IA). The subjects were male and female adults and adolescents; body-weight between groups varied from $3^{8}$ to $6 \mathrm{r} \mathrm{kg}$. Though our adult males were about the same size as Chittenden (1905), who studied long-term low protein intakes in himself and found them satisfactory, it should be noted that $\mathrm{N}$ intakes in our subjects were only one-half or one-third of his values. Within the limits of traditional diets in the highlands, it is virtually impossible for the subjects to escape such low intakes.

We repeated these observations in 1969 , now including also growing children (boys aged Io-r 4 years of about half adult weight, around $25 \mathrm{~kg}$ ) (Fig. IC), prolonging the collection periods from 4 to $6 \mathrm{~d}$, making sure that no change occurred in the usual intake for a week beforehand and extending our studies to different highland localities. There was a variation in the accessory foodstuffs consumed, but $70-100 \%$ of the intakes always consisted of sweet-potatoes. In the lower age groups, averages of food $\mathrm{N}$ intakes were considerably lower, averaging only $\mathrm{I} \cdot 2-2 \cdot 0$ $\mathrm{g} \mathrm{N} / 24 \mathrm{~h}$. Again, all thirty-seven subjects proved to be in negative $\mathrm{N}$ balance; in the youngsters who were known to be growing (albeit slowly), there was a deficit of $\mathrm{r} \cdot \mathrm{O}-\mathrm{r} \cdot 3 \mathrm{~g} \mathrm{~N} / 24 \mathrm{~h}$, and in the adults of $2 \cdot 0-2 \cdot 8 \mathrm{~g} \mathrm{~N} / 24 \mathrm{~h}$. As the quantities and nature of the foodstuffs eaten were common and widespread in the highlands, we cannot avoid the conclusion that negative balances, in the usual usage of this term, must occur quite frequently in the highland population. 

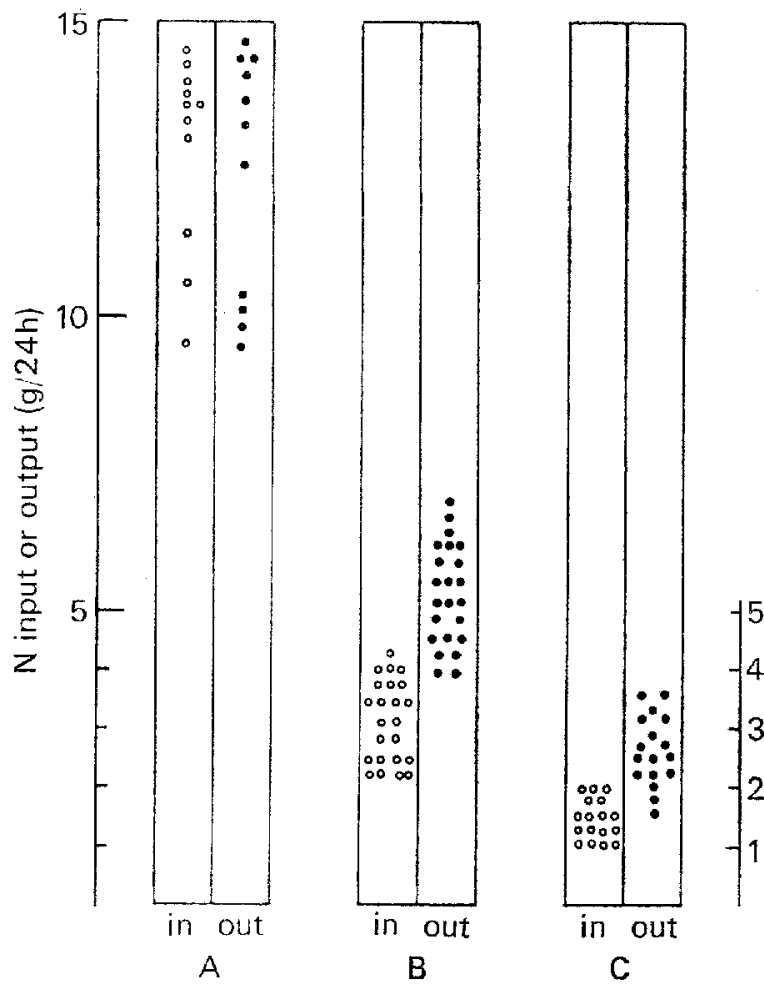

Fig. I. Nitrogen input from food and output in urine and faeces of: (A) a control group of adult Papuans (average weight $56 \mathrm{~kg}$ ) accustomed to a conventional high-protein diet, (B) Ncw Guinean adults (average weight $5 \mathrm{I} \mathrm{kg}$ ) and $(\mathrm{C})$ New Guinean children (average weight $25 \mathrm{~kg}$ ); both groups $B$ and $\mathrm{C}$ were subsisting on the traditional highland sweet-potato diet.

Looking closer at the $\mathrm{N}$ output values (Fig. 2) it appears that the faecal $\mathrm{N}$ values are always large, sometimes even equalling the $\mathrm{N}$ content of the food and exceeding the $\mathrm{N}$ excretion in urine. Faecal $\mathrm{N}$ values of $\mathrm{I} \cdot 2-3 \cdot 2 \mathrm{~g} \mathrm{~N} / 24 \mathrm{~h}$ are not 'abnormal' in themselves but become so when there is a large discrepancy between urinary $\mathrm{N}$ and faecal $\mathrm{N}$. In the $\mathrm{N}$ economy of these subjects the renal output seems to be equal to that of the intestinal. A urinary $\mathrm{N}$ : faecal $\mathrm{N}$ ratio on 'normal' diets would be Io- I5: 1 , whereas the ratio in our subjects was $0 \cdot 6-1 \cdot 5: 1$. The $N$ content of dry stools was usually somewhat lower (about $6 \%$ ) in the sweet-potato eaters than in the control group (about $8 \%$ ) but the absolute quantities were always higher. This was due to the volume of the stools of the sweet-potato eaters, which averaged $250-320 \mathrm{~g} / 24 \mathrm{~h}$ against $90-110 \mathrm{~g} / 24 \mathrm{~h}$, a standard value on usual diets. In addition, the faeces were only seldom faeculent, the odour more resembling decomposing fruit or boiled sweet-potatoes, the colour often being pale, the consistency soft and doughy. These facts suggested a specific intestinal flora.

Could this flora be responsible for the $\mathrm{N}$ deficiency? It is estimated that a quantity of $\mathrm{I} \cdot \mathrm{I} \mathrm{ml} / \mathrm{min}$ of gaseous $\mathrm{N}$ present in $130 \mathrm{ml}$ plasma would be sufficient to allow fixation of $2 \mathrm{~g} \mathrm{~N}$ daily. In view of the constant $\mathrm{N}$ tension of $564 \mathrm{~mm} \mathrm{Hg}$ (Admiraal, 


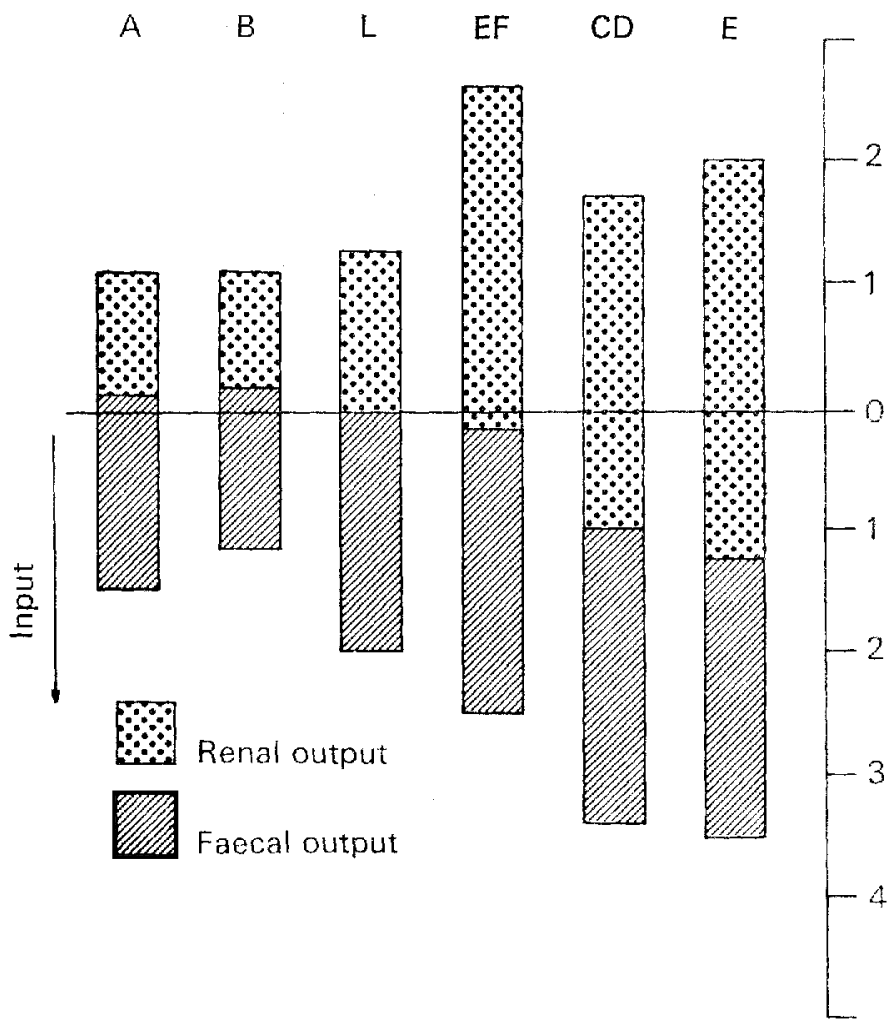

Fig. 2. Nitrogen balances in three groups of children (A, B and $L)$ and three of adults and adolescents (EF, CD and E), all New Guinean sweet-potato eaters. Input is plotted downwards from the base-line; output is plotted upwards from the base of the column representing input. All balances are 'negative'. Note the size of faecal $\mathrm{N}$ output moiety. A, six girls, $3 \mathrm{~d}$, average weight $23 \mathrm{~kg} ; \mathrm{B}$, six boys, 6 d, average weight $23 \mathrm{~kg}$; I., five boys, $5 \mathrm{~d}$, average weight $30 \mathrm{~kg}$; EF, ten adolescent males and females, $3 \mathrm{~d}$, average weight $43 \mathrm{~kg}$; $C D$, thirteen adult males and females, $4 \mathrm{~d}$, average weight $58 \mathrm{~kg}$; $\mathrm{E}$, six adult males, $6 \mathrm{~d}$, average weight $53 \mathrm{~kg}$.

x942), the huge well-vascularized surface of the gut wall and the large intestinal volume, this would not appear impossible. Absorption and diffusion of gases in the intestine are rapid. The fact that $\mathrm{I}-2 \mathrm{air} / \mathrm{d}$ may be swallowed with food is beside the point.

\section{The role of the intestinal microbiota in man}

These facts make it worth while to have a second look at the intestinal processes. Our notions on human nutrition are dominated by the supposition that essential nutrients that cannot be produced or compounded by the tissues must enter the intestinal tract. There is no fermentative apparatus like the stomach-specialization in ruminants and coprophagy is a habit not considered human.

There is, however, a very large mass of microbiota present, especially in the large intestine, to which only a very limited significance has so far been ascribed in host nutrition. In rats the assistance of the intestinal microbiota in providing the host 
organism with thiamine, riboflavine, pyridoxine, etc., has been well documented, especially when coprophagy was not prevented. In man, its usefulness has been suggested by the fact that certain persons fail to show deficiency symptoms when they are expected to do so after inadequate feeding. The most convincing example may be production of vitamin $B_{12}$ in strict vegetarians. This implies that the mucosa of the large intestine is capable of absorbing those products. Although I could find little documentation to support this fact, it must of ten mean that such substances have been liberated from decomposing bacteria, or that they are secreted into the substrate by the micro-organisms.

Most authors concerned with the effects of the microbiota on human nutrition suggest the possibility that amino acids and even protein may become available as a consequence of bacterial synthesis. I quote Dubos ( 1965$)$ : "Since many types of bacteria of the gastrointestinal tract synthesize essential amino acids, it is also possible that the gastrointestinal flora can in certain cases supplement diets consisting primarily of plant products in which the protein composition is inadequate for human growth'. Mitchell ( 1964 ) limits his statement to herbivora but this would include the sweet-potato eaters considered here: 'In herbivora, especially in non-ruminant herbivora, bacterial synthesis also must proceed in the large caecum and colon, and presumably an active resorption of bacterial products occurs there'.

\section{Availability of nutrients in the large intestine}

The crucial question for our purposes is whether, under the conditions of the large intestine, nutrients for the host may still be available. Admittedly, this cannot be of any great significance if the host is sufficiently flooded by nutrients; but could it eventually be useful in a marginal situation?

The absorption of nutrients issuing from microbial digestion has been studied thoroughly in ruminants, but very little is known about it in monogastric mammals. According to Hobson \& Howard (1969), the part played by microbial fermentation in the nutrition of the animal depends on the size of the organ and its spatial relationship. It is impressive in a horse in which the content of the caecum may be 301 . But the types and numbers of the microbes involved, the nature and the quantity of substrate transformed and the products formed by the microbial action are unknown. Either meat or cereal feeds may have a considerable effect on the composition of the intestinal flora. But, though the common intestinal organisms are usually present everywhere in the relatively small volumes of chyme in the ileum, there must be an enormous accumulation in the caecum because of its large contents. According to studies of Smith (I965) in different mammals the qualitative difference of the flora there is mainly due to the sudden increase in the bacteroides moiety. This group then may be responsible both quantitatively and qualitatively for an eventual special character of the flora of the large intestine.

Judging from the size of the evacuations of our subjects, which were two to four times the quantity considered normal, we may assume that the content of their large intestine is also abnormally large. Realizing that we have to bridge a $\mathrm{N}$ 
gap equivalent to an extra protein quantity of 6-12 g daily, the process we rather uneasily suspect must be a very active one.

The intestinal microbiota have been called an organ, in that they are co-ordinated to the physiological processes in the organism (Willingale \& Briggs, 1955). The biological importance is suggested most impressively by the structural changes of the caecum in germ-free animals. As there is no reason to suppose that this state of affairs is different in man, we have to assume that size and structure, which we consider 'normal', especially of the caecum in man, is mainly so because of the presence of intestinal microbiota. It is then not unreasonable to suspect that the potential significance of the caecum may be more important than is commonly accepted by its behaviour in so-called normal man. Is the man we usually consider when studying nutrition biologically normal or is it just he who is adapted to highprotein intakes? Using the weight of healthy adult males as a basis, the requirement of reference protein postulated by a joint $\mathrm{FAO} / \mathrm{WHO}$ expert group (FAO, 1965) would amount to $8 \mathrm{~g} \mathrm{~N} / 24 \mathrm{~h}$. Even without considering the quality of the protein, a normal value in the highland situation would often not exceed half that quantity.

One must have a serious reason to reconsider the significance of the large intestine in human nutrition; I think we have. We are confronted with the necessity of explaining the presence or persistent negative $\mathrm{N}$ balances in a large population, which is not accompanied by any evidence of catabolism.

\section{The presence of $N$-fixing organisms}

Are there bacteria present in the intestine capable of fixing $N$ ? This could be answered with a theoretical affirmative but it has recently been confirmed by investigations of Bergersen \& Hipsley (1970). They isolated N-fixing bacteria from faeces of one out of nine Canberra controls and from all fourteen samples of New Guinean sweet-potato eaters. The best $\mathrm{N}$-fixation was accomplished by cultures provisionally identified as Klebsiella aerogenes (Bacterium aerogenes) but other genera were also involved.

All cultures fixed more $\mathrm{N}$ anaerobically than aerobically, but some fixation occurred when $20 \%$ oxygen was present. The tests used in the experiments were by ${ }^{15} \mathrm{~N}_{2}$ fixation and by the acetylene-ethylene reduction test. It has not yet been established that $\mathrm{N}$-fixation occurs in situ, but the fact that several cultures have been obtained from high dilutions suggest that substantial populations were present. Positive acetylene reduction tests have been obtained, however, from fresh faeces and in a guinea-pig chamber experiment. Some of the strains were stated by Bergersen to be better $\mathrm{N}$-fixers than soil bacteria.

\section{The paradoxical nutritional state}

The hypothesis that $\mathrm{N}$-fixation in the intestine is responsible for the surplus $\mathrm{N}$ persistently found in stools of sweet-potato eaters is then, for the moment, the best explanation we can offer for this puzzling phenomenon. A more pertinent question is, however, whether such excess $\mathrm{N}$ present in the bodies of bacteria can be utilized 
in human nutrition. So far we have only indirect arguments. There was nothing to suggest that any of the subjects were in a catabolic state; periodic measurements of growth in some of the boys known to live on a nearly exclusive sweet-potato diet for a long time in a boarding school proved that they continued growing (Malcolm, 1970). Dr Malcolm also determined mean haemoglobin and serum protein values in the same groups investigated by us. Haemoglobin was $12 \cdot 1 \mathrm{~g} / 100 \mathrm{ml}$, albumin 3.63 and globulin $3.14 \mathrm{~g} / 100 \mathrm{ml}$. Though it can be stated that all the observed adults manifested an excellent nutritional state, the boys were rather thin and small; they were, nevertheless, normal vital schoolboys, and their homeostasis could hardly be doubted. The net protein intakes of the boys were calculated to provide $0 \cdot 22-0.32$ $\mathrm{g} / 24 \mathrm{~h}$ per $\mathrm{kg}$ body-weight; in the adults this was $0.26-0.43 \mathrm{~g} / 24 \mathrm{~h}$. The crude protein values, including non-protein $\mathrm{N}$ may be about $30 \%$ higher. The percentage of calories derived from protein varied in the groups between 3.8 and $6 \cdot 2$.

\section{Range of the 'negative' $N$ balances}

One of our schoolboy groups was used to a skim-milk supplement providing $\mathrm{I} 3 \mathrm{~g}$ of milk protein daily. This was the only group heaving a positive $\mathrm{N}$ balance (input $3.7 \mathrm{~g} \mathrm{~N} / 24$ h, output $2 \cdot 7 \mathrm{~g}$ ) (Fig. 3). This confirms an earlier observation of Luyken,

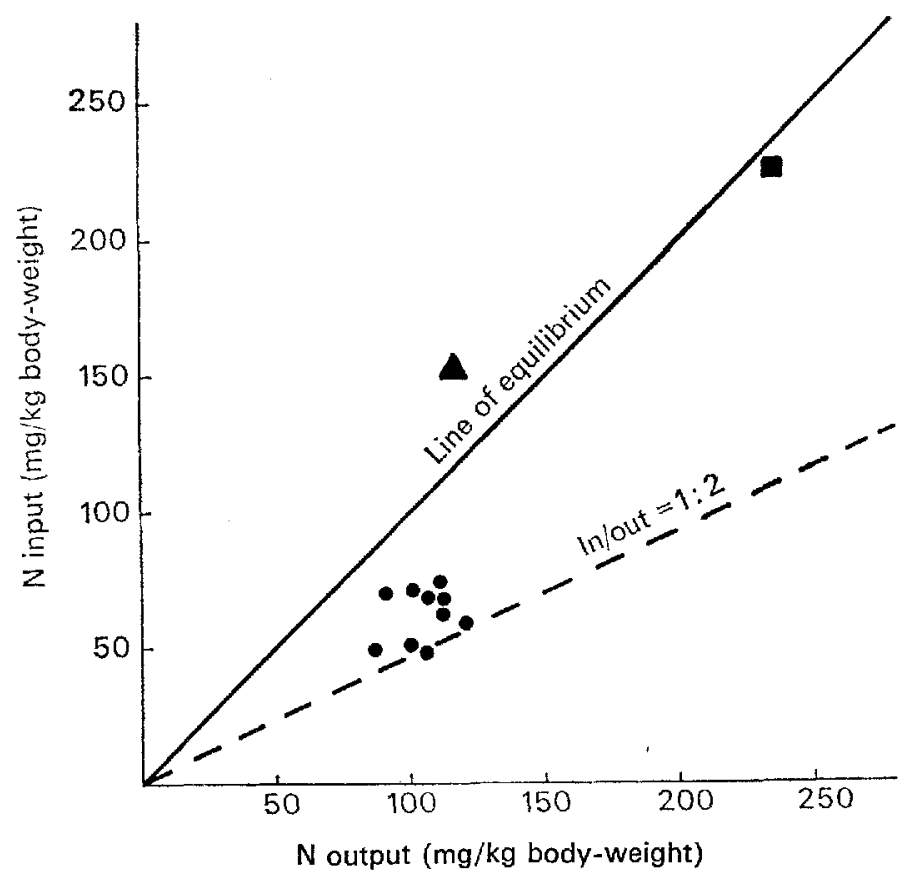

Fig. 3. Nitrogen balance in a control group of adult Papuans accustomed to a high-protein rice-meat diet ( $\mathrm{B}$ ), New Guineans (average weight $23-58 \mathrm{~kg}$, sixty persons $266 \mathrm{~d}$ ) subsisting on sweet-potatoes (C), and boys eating the normal diet of sweet-potatoes supplemented with milk to provide an extra $13 \mathrm{~g}$ protein daily $(\mathbf{A})$. The control group is in $\mathrm{N}$ equilibrium; New Guineans on the sweet-potato diet show relatively considerable negative balance; the boys receiving the supplemented diet show a positive balance. 
Luyken-Koning \& Pikaar (1964) who, using various protein supplements in similar subjects, could not achieve a positive balance below $4.5 \mathrm{~g} \mathrm{~N} / 24 \mathrm{~h}$. However, they did not comment on the negative balances which they found, but they also reported very large faecal volumes.

The question then is, on which level of $\mathrm{N}$ intake do the balances become positive? Is the positivity then observed a true measure of $\mathrm{N}$ retained or does it indicate a spurious value, as we have to suppose for the negative balances? Our tentative concept at present is that the intestinal microbiota tend to achieve a constant dryweight $\mathrm{N}$ percentage which, with higher intake, may be limited by lesser faecal volumes, and consequently with a smaller faecal $\mathrm{N}$ output.

\section{Discussion}

The validity of $\mathrm{N}$ balance depends on the assumption that no $\mathrm{N}$ is lost in volatile forms and that no $\mathrm{N}$ is fixed by the animal (Owen, 1967 ). In addition, $\mathrm{N}$ compounds, especially those in food, should not escape determination by the Kjeldahl method. Only renal and intestinal pathways are involved (dermal losses being usually small and neglected) in output of $\mathrm{N}$. This assumption has been challenged, or exceptions have been suspected, in several recent metabolic studies. Fisher, Brush, Griminger \& Sostman ( 1967 ) could not retrieve the $\mathrm{N}$ of intakes over ${ }_{15} \mathrm{~g} \mathrm{~N} / 24 \mathrm{~h}$ in urine and stools of young adults, nor was it possible to prove that it was retained as tissue N. They suggested that it was stored as non-protein N. Deosthale, Vasantgadkar \& Tulpule (1964) suggested that it may be possible that the intestinal flora associated with vegetable protein diets might favour the conversion of amides of vegetable origin into gaseous $\mathrm{N}$, which might escape detection'. These authors experimented with high-calorie diets containing about II $\mathrm{g} \mathrm{N} / 24 \mathrm{~h}$. The most pertinent observations have been reported by Costa, Ullrich, Kantor \& Holland (ig68) who proved that excess $\mathrm{N}$ was present in the expired air of man and mice loaded up to high-calorie high-protein levels. This, and the presence of hydrogen in the expired air, was ascribed also to the activity of intestinal flora. These examples illustrate that the intestinal flora interferes in $\mathrm{N}$ metabolism and that it is also operative when $\mathrm{N}$ intakes are high. As theirs is the reverse situation, it may suggest a certain compensatory regulation by the intestinal flora reacting on the qualities of the available substrate. It further suggests a similarity of nitrification and denitrification processes present in humus. In a sense, faeces could be considered as 'instant humus'.

Albanese, Davis, Lein \& Smetak (1948) have isolated a faecal protein, different from dietary protein, from infants receiving $3.5 \mathrm{~g} \mathrm{~N} / \mathrm{roo} \mathrm{kcal}$ per $\mathrm{kg}$ per d. This 'fecanin' they supposed to represent $2-27 \%$ of the faecal $\mathrm{N}$; it did not contain bacteria, it had a uniform and typical amino acid pattern, it was supposed to be independent of diet and originating from specific intestinal secretions. Though these experiments prove the presence of a high-quality protein in the lumen, it is biologically incomprehensible how such a protein could remain intact among the milliards of bacteria pullulating in the large intestine. 
The curious facts reported here would not be complete without mentioning two nutritional aspects which seem to be specific to the highland sweet-potato eaters. The first is the presence of relatively large quantities of hippuric acid in the urines, amounting to $10-20 \%$ of the total urinary $\mathrm{N}$. The second is the frequent occurrence in this environment of an often fatal enteritis necroticans ('pig-bel') due to Clostridium perfringens which is observed at the rare festive occasions when the highlanders indulge in large quantities of pork (Murrell, Egerton, Rampling, Samels \& Walker, 1966). Then the high carbohydrate-low protein diet suddenly changes to a high-protein high-fat one. Stating the coincidence may suffice now; the interpretation, however, would be a different story.

Our findings open many new perspectives. Would the phenomenon observed be present exclusively in sweet-potato eaters? A few values available now for groups subsisting on taro and cassava suggest similarities. The predominantly starchy quality of their diet may also result in the presence of abnormally large quantities of starch in the caecum, the principal agent we suspect in causing a particular flora. Whether it is due to sweet-potato, or to low-protein starchy staple foods dominating the diet in many of the humid tropical regions, or to a specific adaptation of the intestinal flora, it might explain the diet-nutritional state paradox witnessed by many investigators of the 'Ipomoea oecosystem' in the highlands of New Guinea. If the usefulness of such a secondary $\mathrm{N}$ cycle in our subjects could be proved they could be called 'walking legumes'. One could state anyway that the sweetpotato eaters are very well adapted to a high-carbohydrate low-protein diet but that they are not adapted to a high-protein high-fat diet, except when they have developed immunity against the Clostridium of pig-bel.

The facts on which these speculations are based are admittedly meagre. So far only a few $\mathrm{N}$ values are available, but they are consistent and reproducible. The problem they raise is whether, at marginal protein intakes, biological mechanisms, which remain hidden in man at high intakes, can play a part in achieving homeostasis.

\section{REFERENCES}

Admiraal, J. (1942). Onderzoek over de gasresorptie in darmen. Thesis, University of Amsterdam. Albanese, A. A., Davis, V. T., Lein, M. \& Smetak, E. M. (1948). 7. biol. Chem. r76, I 89 .

Bailey, K. V. (1963). Fd Nutr. Notes Rev, 20, 89.

Bergersen, F. J. \& Hipsley, E. H. (1970). F. gen. Microbiol. 60, 61.

Chittenden, R. H. (1905). Physiological Economy in Nutrition. London: Heinemann.

Costa, G., Ullrich, L., Kantor, F. \& Holland, J. F. (1968). Nature, Lond. 218, 546.

Deosthale, Y. G., Vasantgadkar, P. S. \& Tulpule, P. G. (1964). Indian 7. med. Res. 52, II I.

Dubos, R. J. (1965). Man adapting p. 129. New Haven, Conn.: Yale University Press.

FAO (ig65). F.A.O. Nutr. Mtg Rep. Ser. no. 37.

Fisher, H., Brush, M. K., Griminger, P. \& Sostman, E. R. (1967). Am. F. clin. Nutr. 20, 927.

Hobson, P. N. \& Howard, B. H. (1969). In Handbuch der Tierernähnng p. 242 [Lenkeit, Breirem and Crasemann, editors]. Hamburg and Berlin: Paul Parey.

Luyken, R., Luyken-Koning, F. W. M. \& Pikaar, N. A. (1964). Am. J. clin. Nutr. 14, г3.

Malcolm, L. A. (1970). Br. F. Nutr. 24, 297.

Mitchell, H. H. (1964). Comparative Nutrition of Man and Domestic Animals p. 443. New York: Academic Press.

Murrell, T. G. C., Egerton, J. R., Rampling, A., Samels, J. \& Walker, P. D. (1966). J. Hyg., Camb. 64,375 . 
Oomen, H. A. P. C. \& Corden, M. W. (1970). Tech. Pap. S. Pacif. Commn. No. I63

Oomen, H. A. P. C., Spoon, W., Heesterman, J. E., Ruinard, J., Luyken, R. \& Slump, W. (I96r). Trop, geogr. Med. $\mathbf{1 3}, 55$.

Owen, E. C. (1967). Proc. Nutr. Soc, 26, I16.

Smith, H. W. (1965). F. Path. Bact. 89, 95.

Willingale, J. M. \& Briggs, C. A. E. (1955). F. appl. Bact. 18, 284.

\section{Experimental protein-calorie deficiency}

\section{By R. J. C. STEwart, Department of Human Nutrition, London School of Hygiene and Tropical Medicine, Keppel Street, London, WC1}

Many investigations into the effects of malnutrition have as their background the severe calorie and protein deficiencies associated with underdeveloped countries (McCance \& Widdowson, 1968). Mr Miller has already demonstrated that the protein value of a diet is best expressed as net dietary-protein calories \% (NDpCal $\%$ ), a value that can be obtained by biological assay (Platt \& Miller, 1959). The value of a diet is reduced when it is diluted with fat or carbohydrate, or, as is less widely appreciated, from the consumer's point of view when it is eaten in inadequate amounts (Platt, Miller \& Payne, 1961). Both dietary conditions produce protein-calorie deficiency, as defined by the Joint FAO/WHO Expert Committee on Nutrition (WHO, I962), but the severity of the various symptoms may differ widely. For example, a deficiency produced by feeding an animal on grossly inadequate amounts of a well-balanced diet may lead to a greater inhibition of weight gain than occurs in another animal given unlimited quantities of a diet of low protein value; but the second animal will have the greater amount of body water and fat and a lower concentration of albumin in its serum. The low serum albumin will reduce the transport of albumin-bound vitamin A and calcium (Friend, Heard, Platt, Stewart \& Turner, 1961; Gutman, 1953).

From his experiences in China, Platt (1958) became convinced that there was an underlying 'protein malnutrition' in beriberi and probably in other vitamin deficiency states. Certainly, when animals are given diets containing insufficient amounts of vitamins or minerals, for instance thiamine (Cowgill, Deuell \& Smith, 1925), retinol (Mellanby, I950) and calcium (El-Maraghi, Platt \& Stewart, 1965), there is often a severe loss of appetite, so that the original deficiency is complicated by some degree of protein-calorie deficiency. Platt believed also that there was an element of protein-calorie deficiency in most, if not all, diseased subjects. Overseas students working in his unit demonstrated that, in rats infected with Plasmodium berghei (Dema, 1959) and Nippostrongylus muris (Orraca-Tetteh, 1964) and in dogs carrying heavy loads of Toxocara canis (Al-Rabii, 1963), the value of the diet to the infected animal was about half that to the uninfected control. Part of this reduction could be related to a reduced intake of food, but the value to infected animals was also lower than to uninfected pair-fed controls. The precise nature of this phenomenon 